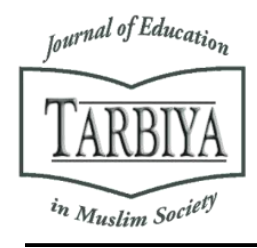

Available online at TARBIYA: Journal of Education in Muslim Society Website:

http://journal.uinjkt.ac.id/index.php/tarbiya

TARBIYA: Journal of Education in Muslim Society, 6(1), 2019, 1-9

\title{
THE OMANI DISTANCE LEARNING PROGRAM TO TEACH THE HOLY QURAN:
} ANALYTICAL DESCRIPTIVE STUDY

\author{
Salem Al Akhzami ${ }^{1}$, Abdullah Al Hinai ${ }^{2}$, Ali Al Musawi ${ }^{2}$ \\ ${ }^{1}$ Ministry of Education, Muscat, Oman \\ ${ }^{2}$ Sultan Qaboos university, Muscat, Oman \\ E-mail: asmusawi@squ.edu.om
}

Received: $19^{\text {th }}$ March 2019; Revised: $25^{\text {th }}$ April 2019; Accepted: $28^{\text {th }}$ June 2019

\begin{abstract}
This study aimed to investigate the usefulness of Omani distance-learning program to teach the Holy Quran and identify its advantages and disadvantages as viewed by the program stakeholders (administrators, teachers, students). The study used both analytical and descriptive approaches. The study sample was selected using purposive sampling to be representative of the study community of administrators, teachers and students. A survey questionnaire, consists of 19 statements, was designed and measured to ensure its validity and reliability. The findings indicated high satisfaction among the stakeholders on most items of the questionnaire with regard to the educational components of the program with a mean score of 4.16. Additionally, the findings showed that there was no statistically significant difference between the stakeholders' views in terms of the gender, both male and female, variables. The study recommended that the program administrators should work to enhance the positive aspects of the program highlighted by the study and to avoid the passivity emerged from the study.
\end{abstract}

Keywords: electronic program; distance learning; quran

\section{Abstrak}

Penelitian ini bertujuan menyelidiki kegunaan program pembelajaran jarak jauh di Oman untuk mengajarkan Al-Quran dan untuk mengidentifikasi kelebihan dan kekurangan yang dilihat oleh para pemangku kepentingan program (administrator, guru, siswa). Penelitian ini menggunakan pendekatan analitis deskriptif. Sampel penelitian dipilih menggunakan purposive sampling untuk mewakili komunitas studi dari administrator, guru dan siswa. Kuesioner survei yang terdiri dari (19) pernyataan dirancang dan diukur untuk memastikan validitas dan reliabilitasnya. Temuan menunjukkan kepuasan yang tinggi di antara para pemangku kepentingan pada sebagian besar item kuesioner berkenaan dengan komponen pendidikan program dengan skor rata-rata $(4,16)$. Selain itu, temuan menunjukkan bahwa tidak ada perbedaan yang signifikan secara statistik antara pandangan para pemangku kepentingan dalam hal variabel gender (pria / wanita). Studi ini merekomendasikan bahwa administrator program harus bekerja untuk meningkatkan aspek positif dari program yang disorot oleh penelitian dan untuk menghindari kepasifan yang muncul dari penelitian.

Kata kunci: program elektronik; pembelajaran jarak jauh; quran

How to Cite : Al Akhzami, S., Al Hinai, A., Al Musawi, A. (2019). The Omani Distance Learning Program to Teach the Holy Quran: Analytical Descriptive Study. TARBIYA: Journal of Education in Muslim Society, 6(1), 1-9. doi:10.15408/tjems.v6i1.11182.

Permalink/DOI: http://dx.doi.org/10.15408/tjems.v6i1.11182

TARBIYA: Journal of Education in Muslim Society, p-ISSN: 2356-1416, e-ISSN: 2442-9848

This is an open access article under CC-BY-SA license (https://creativecommons.org/licenses/by-sa/4.0/) 


\section{Introduction}

The teaching of the Holy Quran in the Islamic countries was spread through the guidance and the applications of Prophet Mohamed (PBUH). The parents first sent their children to the institutions of teaching the Holy Quran: mosques, 'Kuttab" (traditional open schools), and then to the Quranic schools after their establishment. In the modern era, modern technologies opened up many opportunities for learning and education. These developments are joined with clear efforts to integrate and adapt these technologies to serve the divine verses and teach the Quran through the Internet and other e-learning means (Rajab, 2009; Al-Sabihi, 2009). For example, Hidayat (2017) explained that to accommodate the increasing demand for quality Islamic education, students need "to practice self-learning or distance learning with technology such as E-learning" (p. 21). Itmazi (2011) suggested a flexible framework to establish technological centers to serve the Holy Quran teaching purposes. He proposed an integrated educational and training service, e-learning tools and techniques combined with the popular tools available to provide services for the instructional process. Shamsuddin et al. (2016) and Mssraty and Faryad (2015) designed game-based guidelines and pedagogy for mobile technology and multimedia learning systems to make memorizing Quran effective for children in primary education. These views are echoed by other researchers (Mohamed, et al., 2014; Suleiman, 2012; Abdullah, 2011; Madani, 2010).

In the Sultanate of Oman, most of the public and higher education institutions have implemented the concept of e-learning, in which instruction and training are presented to the learners over the Internet (Al Musawi, 2018 \& 2010). Omani teachers mostly use computer and web-based technologies to deliver their lessons (Al Musawi et al, 2016). A Distance Learning
Program (DLP) to teach the Holy Quran was launched early in 2015 and was supervised by the Ministry of Awqaf and Religious Affairs. It provides the stakeholders with multiple programs, based on a new innovative approach called "The Seven Forts Approach to Memorize the Quran", named after the Omani well-known history of forts-building. The DLP also includes a course in the Quranic Recitation (Tajweed) called "The Simplified cycle of Tajweed". The program usually starts with an introductory period to introduce the program to the student with a training phase to develop the e-learning skills of the learner. A system exists to motivate the students in their progress by collecting points of digital badges and 'diamonds'. The students' daily tasks in the DLP are as follows (Ministry of Awqaf and Religious Affairs, n.d.):

- Two days: Memorize, review and recall.

- One Day: Review, recall and then recite with the teacher.

- Two days: Memorize, review and recall.

- One Day: Review, recall and then recite with the teacher.

- One Day: Comprehend and review what has been memorized during the week.

The students performed these tasks electronically through methods based on excitement, encouragement and fun using a virtual points-grading system where they collect points whenever they complete a task. They usually continue with all the tasks without an intervention or a follow up by the teacher except only for the two-hour recitation sessions, which take place synchronously on two different weekdays during direct electronic meetings with the teacher (Ministry of Awqaf and Religious Affairs, n.d.). AlZoubi, (2013) recommends this model stating that: "the best model that facilitates the practical instruction in the transfer and teaching of Quran 
recitations online is the electronic-Miqrah (Recitation), where both the teacher and the student meet and communicate through voice and images directly" (p.1).

The role of the teacher in the program is of a supervisory type through the evaluation of students' memorization and the follow up of their Quranic reading by teaching them the correct recitation. The teacher also, in some programs, teaches lessons in Tajweed. The entire instructional activities are provided directly through the program website (Ministry of Awqaf and Religious Affairs, n.d.).

The following is a review of some previous studies about distance learning programs using the Internet and/or related technologies:

- "Using Electronic Technology in Education Instruction and Religious Dissemination" by Al-Jaid (2004), a paper presented at the Seventeenth National Conference on Computer (Informatics in the Service of Pilgrims). The study aimed to introduce the needs of using modern communication and electronic software and adapted them in the dissemination of Islam. In addition, it presented the experience of a Saudi Society to memorize the Quran in this area, including its website and use of Paltalk and emails.

- "Teaching the Holy Quran by Distance Learning: Descriptive and Analytical Study of Some Experiments" by Al-Farih (2009), a paper presented in the symposium of the Holy Quran and contemporary technologies. It sought to study the method of teaching the Holy Quran using distance-learning methods through the Internet and analyse them. It explained the advantages of these methods, identified their weaknesses, and determined their effects. It concluded with the presentation of real experiences of teaching Quran by distance learning in different countries. The most important finding of this study was the existence of educational institutions that is considered the teaching of Quran by distance learning through the Internet along with the need to consider the privacy of Muslim women by providing female teachers. It recommended caring about the Quran interpretation and its educational values.

- "An Analytical Study of Governmental Internet Sites on the Holy Quran and its Sciences in the United Arab Emirates: Reality and Visions (The Sites of the Quran and Sunnah Foundation in Sharjah $\&$ the Dubai International Award for the Holy Quran as a Model)" by Al-Khatib (2009). This study presented, evaluated and compared two Quranic websites; the Foundation of the Holy Quran and Sunnah in Sharjah and the Dubai International Prize for the Holy Quran. The study aimed to answer the following questions: "To what extent do the public accept these sites? How satisfied are they with them? What is their assessment of these two sites? What are their proposals for developing the sites?" The sample of the study consisted of 89 participants, 83 of whom were students and six were professors. The study used the descriptive survey method and the questionnaire as main instruments. The findings of the study showed that there is general satisfaction with both websites, and that there is an urgent need to modify, develop and improve some aspects in the websites, such as providing additional multimedia components and accelerating their time of opening. It recommended to conduct in-depth studies of Internet sites specialized in the teaching of Quran and 
Sunnah based on modern research methods.

The researchers benefited from these studies in their methodology and procedures along with the interpretation of this study findings and recommendations.

\section{Importance of the Study}

It is expected that this study will: 1) Raise the awareness about the importance of the electronic program to teach the Holy Quran using distance learning; 2) Provide data on the status of DLP to teach the Holy Quran in Oman and elsewhere; 3) Assist decision-makers to develop plans to improve DLP and activate its role; 4) Motivate specialized researchers and scholars to conduct studies that would improve the teaching methods of the Holy Quran, specifically those related to the technological advances.

\section{Study Problem}

The teaching of the Holy Quran needs to be developed in its methods and techniques. In the recent times, the methods of teaching the Holy Quran through the Internet has begun to appear because of the urgent need to adopt contemporary innovations and outreach other communities. Islamic Internet sites are considered new, specifically the Omani DLP, to teach the Holy Quran (the case under study) as it has appeared less than three years ago. Since the program is in its first years, the need to study it is persistent to introduce it to the research community, highlight its advantages and weaknesses, and evaluate its prospective improvements.

The problem can be formulated in the following question: "What is the usefulness of the Omani DLP to teach the Holy Quran as viewed by the stakeholders (administrators, teachers, students)? The following sub-questions emerged from this research question: 1) What are the educational advantages and disadvantages of the Omani DLP to teach the Holy Quran as viewed by the stakeholders?; 2) Are there any statistically significant differences between the stakeholders in terms of the gender variable: male and female?.

The following Objectives of the study: 1) Verify the usefulness of the Omani DLP to teach the Holy Quran according to the views of the stakeholders (administrators, teachers, students); 2) State the pros and cons of the DLP to teach the Holy Quran according to the views of those stakeholders; 3) Detect the existence of any statistical differences among the views of the stakeholders in terms of the gender variable (male and female).

\section{Method}

The researchers first identified the problem of the study, its questions and objectives; and reviewed previous studies. Accordingly, the descriptive analytical approach is deemed the most appropriate method to conduct this type of study.

\section{Study community and sample}

The study community consisted of all the stakeholders at the Omani DLP to teach the Holy Quran (administrators, teachers, students), distributed all over the eleven governorates of the Sultanate of Oman, registered in the second semester of the academic year 2017-2018 and summed at (6) administrators, (30) teachers and (1600) students.

Due to the large number of the study community and its wide geographical distribution, a representative sample was purposively selected. The number of questionnaires distributed electronically, completed and received back was (63). This sample of male and female respondents represented $100 \%$ of the administrators, $73 \%$ of 
the teachers and $2.2 \%$ of the students. Table 1 shows the sample of the study.

Table 1. Distribution of study sample

\begin{tabular}{lllll}
\hline Item & Type & & Total \\
\cline { 2 - 3 } & Administrator & Teacher & Student & \\
Male & 4 & 4 & 18 & 26 \\
Females & 2 & 18 & 17 & 37 \\
Total & 6 & 22 & 35 & 63 \\
\hline
\end{tabular}

\section{Study instrument}

To answer the study questions and achieve the study objectives, the researchers used the questionnaire as a tool to describe and analyze the phenomenon studied according to the study methodology, taking into consideration the size of the community and its geographical distribution.

The researchers have conducted according to the research method to design the questionnaire, verify its validity, and ensure its reliability to reach the final form and achieve its purposes. To ensure the content validity of the questionnaire, it was reviewed by eight specialists. To verify the questionnaire reliability, the reliability coefficient (Cronbach's Alpha) was calculated and was at 0.84 for all the questionnaire statements, which indicated that the instrument has high reliability.

After establishing the validity and reliability of the questionnaire, the researchers administered the questionnaire in the field according to the following procedures: 1) Changing the questionnaire to an online format using the services of Google ${ }^{\circledR}$ Docs to secure the stakeholders' access to the questionnaire; 2) The researchers requested the staff of the Omani DLP to share the link of the online questionnaire with the participants (63 administrators, teachers and students) after selection (as listed in Table 1); 3) On the return of responses, data were statistically entered and analyzed using the Statistical Package of Social Sciences (SPSS).

\section{Statistical analysis}

To arrive at the findings, the following statistical analysis methods were used: 1) Cronbach Alpha coefficient to measure the reliability of the questionnaire. 2) Standard deviation and means. 3) T-test.

\section{Results and Discussion}

The researchers present the findings of the questionnaire, analyze and discuss them below, in order to answer the questions of the study.

First Research Question: The study sample was asked to express their views about the educational components of the DLP on an estimated scale of five alternatives: (strongly agree), (agree), (neutral), (disagree), (strongly disagree) valued as (4), (3), (2), (1) respectively. Means and standard deviations were used for the analysis of responses. Table 2 shows the results.

Table 2. Statistical means and standard deviations of the sample responses on the educational components of the program $\left(^{*}\right)$

\begin{tabular}{|c|c|c|c|}
\hline No & Statements & $\begin{array}{l}\text { Mea } \\
\text { n }\end{array}$ & $\begin{array}{l}\text { Standard } \\
\text { Deviation }\end{array}$ \\
\hline 1 & $\begin{array}{l}\text { The content of the Tajweed course is } \\
\text { accurate. }\end{array}$ & 4.25 & 0.65 \\
\hline 2 & $\begin{array}{l}\text { The program requests learners to perform } \\
\text { non-electronic activities, such as reviewing } \\
\text { references in Tajweed principles. }\end{array}$ & 3.35 & 1.36 \\
\hline 3 & $\begin{array}{l}\text { The program includes clear objectives for } \\
\text { the programs/curricula offered. }\end{array}$ & 4.14 & 0.82 \\
\hline 4 & $\begin{array}{l}\text { The program was designed to support } \\
\text { learners' self-learning in memorizing, } \\
\text { reviewing, and retrieving the Quranic verses. }\end{array}$ & 4.73 & 0.48 \\
\hline 5 & $\begin{array}{l}\text { By reading the course description, the } \\
\text { learner can know the Tajweed principles } \\
\text { that s/he will acquire when s/he completes } \\
\text { the program s/he has chosen. }\end{array}$ & 3.60 & 1.23 \\
\hline 6 & $\begin{array}{l}\text { Directions to learners towards daily learning } \\
\text { tasks enhances their ability to navigate } \\
\text { smoothly through the program. }\end{array}$ & 4.62 & 0.52 \\
\hline 7 & $\begin{array}{l}\text { Teacher's assessment during/after the } \\
\text { synchronous sessions develops learners' } \\
\text { performance. }\end{array}$ & 4.18 & 1.21 \\
\hline 8 & $\begin{array}{l}\text { 'Introductory Period' experience reduces the } \\
\text { anxiety of the learner. }\end{array}$ & 3.94 & 0.90 \\
\hline 9 & $\begin{array}{l}\text { The training phase addresses the lack of the } \\
\text { e-learning skills of the learner. }\end{array}$ & 4.22 & 0.68 \\
\hline 10 & $\begin{array}{l}\text { Digital badges and diamonds points system } \\
\text { increases student motivation towards } \\
\text { achievement and competition. }\end{array}$ & 4.73 & 0.52 \\
\hline 11 & $\begin{array}{l}\text { Learners receive continuous feedback about } \\
\text { their performance in tasks. }\end{array}$ & 4.25 & 0.82 \\
\hline 12 & The program takes into account equal & 4.73 & 0.72 \\
\hline
\end{tabular}




\begin{tabular}{|c|c|c|c|}
\hline No & Statements & $\begin{array}{l}\text { Mea } \\
\mathrm{n}\end{array}$ & $\begin{array}{l}\text { Standard } \\
\text { Deviation }\end{array}$ \\
\hline & $\begin{array}{l}\text { consideration of gender issues in } \\
\text { synchronous sessions. }\end{array}$ & & \\
\hline 13 & $\begin{array}{l}\text { The program allows the learner to be able to } \\
\text { control the learning environment freely, in } \\
\text { terms of selecting appropriate school days } \\
\text { and times. }\end{array}$ & 4.41 & 1.19 \\
\hline 14 & $\begin{array}{l}\text { In the synchronous sessions, the teacher has } \\
\text { the skills of providing information and } \\
\text { Tajweed principles to the learner. }\end{array}$ & 4.30 & 0.84 \\
\hline 15 & $\begin{array}{l}\text { The seven forts approach helps to preserve, } \\
\text { strengthen, retain, and retrieve the } \\
\text { memorization course quickly. }\end{array}$ & 4.67 & 0.51 \\
\hline 16 & $\begin{array}{l}\text { The day-to-day task enhancement and } \\
\text { reiteration feature promotes learners' } \\
\text { remembrance and retention. }\end{array}$ & 4.67 & 0.51 \\
\hline 17 & $\begin{array}{l}\text { The program allows interpretation of the } \\
\text { Quranic verses or stating their overall } \\
\text { meaning. }\end{array}$ & 2.52 & 1.26 \\
\hline 18 & $\begin{array}{l}\text { The program sets clear assessment criteria } \\
\text { for learners. }\end{array}$ & 3.48 & 1.37 \\
\hline 19 & $\begin{array}{l}\text { The presence of the study plan in the } \\
\text { program helps to measure learners' } \\
\text { achievement and interaction. }\end{array}$ & 4.19 & 0.93 \\
\hline
\end{tabular}

Table 2 shows the stakeholders' responses on the statements about the educational components of DLP. It clarifies that: 1) The means are between (3.35) and (4.73). This means that the respondents have agreed to (18) educational components of the program, as their means were greater than the theoretical average (3); 2) The responses of the stakeholders revealed that the following statements are positive responses with the highest means of (4.73):

- Statement (4): 'The program was designed to support the learners' self-learning in memorizing, reviewing, and retrieving the Quranic verses,

- Statement (10): 'Digital badges and diamonds points system increases student motivation towards achievement and competition' and;

- Statement (12): 'The program takes into account with equal consideration of gender issues in synchronous sessions'.

These findings were consistent with Rajab's study (2009), which concluded that the multimedia e-learning method promoted the culture of self-learning and training through computers and Internet. Moreover, the above results have agreed with Al-Subaihi (2009), Shamsuddin et al. (2016) and Mssraty, and Faryad (2015) to introduce learning through games in the teaching of Quran to increase its effectiveness among children. The findings also substantiated the results of Al-Farih study (2009), which was emphasized Muslim women's particularity in terms of learning the Holy Quran through the Internet female teachers; 3) Stakeholders' responses show that statement (17): 'The program allows interpretation of the Quranic verses or stating their overall meaning' has obtained a passive response with the least mean of (2.52), which indicates that this component is not available in the program. This finding differs with Al-Farih (2009) and Rajab (2009) studies, which recommended the need to care about the Quran interpretation and establish a specialized and documented information database to show the students the scientific miracles of the Holy Quran. It also differs with Al-Subaihi (2009) and Itmazi (2011) studies, which proposed establishing an electronic framework and storyteller to support Quran teaching; 4) Table 2 shows that the statements about the educational components of the program, have received conformity of all respondents with an overall mean of (4.16), indicating high satisfaction among program stakeholders for most of those components.

Second Research Question: To investigate the effect of the gender variable on the respondents' evaluation of the program, T-test was conducted. Table 3 shows the findings of this test.

Table 3. T-test results of the gender variable for responses on beneficiary evaluation of the program

\begin{tabular}{|c|c|c|c|c|c|c|}
\hline Theme & Gender & $\mathbf{N}$ & $\begin{array}{l}\text { Mea } \\
n\end{array}$ & $\begin{array}{l}\text { Standard } \\
\text { deviatio } \\
\mathrm{n}\end{array}$ & $\mathrm{T}$ & Sig. \\
\hline $\begin{array}{l}\text { Educatio } \\
\text { nal } \\
\text { compon } \\
\text { ents }\end{array}$ & $\begin{array}{l}\text { Males } \\
\text { Females }\end{array}$ & $\begin{array}{l}26 \\
37\end{array}$ & $\begin{array}{l}4.10 \\
4.20\end{array}$ & $\begin{array}{l}0.57 \\
0.37\end{array}$ & $\begin{array}{l}0.8 \\
9\end{array}$ & $\begin{array}{l}\text { Not } \\
\text { significan } \\
t\end{array}$ \\
\hline
\end{tabular}


It is noted from Table (3) that the T-test results indicate that there are no statistically significant differences between the views of the stakeholders with respect to the gender variable in terms of the program educational components. This indicates equal perceptions of male and female stakeholders towards the program evaluation, concerning its usefulness. This finding can be attributed to the equal services provided for both sexes, specifically during the synchronous sessions. This was highly rated in statement (12) above. In addition, it reflects the logistical flexibility, easiness and accessibility of the program as felt and perceived by all stakeholders regardless of their gender type. Al-Farih (2009) explains that Muslim women prefer learning the Holy Quran online by female teachers, a case applicable to the Omani DLP with more female than male teachers do (as seen in Table 1).

\section{Conclusions}

By this, it could be concluded that: 1) There was high satisfaction among the stakeholders of the program for most of the questionnaire's statements on its educational components; 2) The most positive educational features of the DLP as viewed by the stakeholders were its: design to support learners' self- learning in memorizing, reviewing, and retrieving the Quranic verses, ability to use the points system to increase students' motivation towards achievement and competition, equal consideration of gender issues in synchronous sessions; 3) The study revealed that the most important educational component that the program needs to provide was to allow interpretation of the Quranic verses or stating their overall meaning. On the other hand, the least important component was to set clear criteria of students' evaluation, as those seem to be already in place; 4) The male and female stakeholders hold equal perceptions towards the evaluation of the educational components of the program.

\section{Recommendations}

In the light of the findings, it can be recommended that: 1) The programmers work to enhance the positive features of the DLP highlighted in the study and avoid the negative ones; 2) The program administrators hold seminars and panel discussions on the technological efforts to serve the teaching of the Holy Quran in the Sultanate of Oman.

\section{References}

Abdullah, Z. (2011). Effectiveness of interpretative reading strategy using multimedia in the mastery of recitation and teaching of the Holy Quran unit for sixth grade students, Specific Education Research Journal, 23(2), 761-790. Al Mansoura Univ. Egypt.

Al Musawi, A. (2018). Chapter 13: Oman, In Weber, A. and Hamlaoui, S. (Ed.) ELearning in the Middle East and North Africa (MENA) Region, Pp. 285-308, Springer. http://dx.doi.org/10.1007/9783-319-68999-9.

Al Musawi, A. (2010). E-Learning from an Omani Perspective, In Demiray, U. et al. (eds.), Cases on Challenges Facing ELearning and National Development : Institutional Studies and Practices, Chapter 25, Volume II, Pp. 603-626; ERIC Doc. No. ED508217, Available: http://akgul.bilkent.edu.tr/egitim/FINAL_ ELEARN_EBOOK_VOL2.pdf

Al Musawi, A., Al Hashmi, Abdullah, Kazem, Ali Mahdi, Al Busaidi, Fatima, and Al Khaifi, Salim (2016). Perceptions of Arabic language teachers toward their use of technology at the Omani basic education schools, Education and 
Information Technologies, 21(1), 5-18, DOI: $10.1007 / s 10639-013-9305-5$.

Al-Farih, A. (2009). Teaching the Holy Quran by Distance Learning: Descriptive and Analytical Study of Some Experiments, Symposium on the Holy Quran and Contemporary TechnologiesOctober 13-15, 2009; King Fahad Complex for Printing the Holy Quran, Madinah: KSA.

Al-Jaid. F. (2004). Using Electronic Technology in Education Instruction and Religious Dissemination, Paper presented at the $17^{\text {th }}$ National Conference on Computer: Informatics in the Service of Pilgrims, King Abdul-Aziz University, Madinah: KSA.

Al-Khatib, A. (2009). An Analytical Study of Governmental Internet Sites on the Holy Quran and its Sciences in the United Arab Emirates: Reality and Visions (The Sites of the Quran and Sunnah Foundation in Sharjah \& the Dubai International Award for the Holy Quran as a Model), Symposium on the Holy Quran and Contemporary Technologies (Information Technology), King Fahad Complex for Printing the Holy Quran, Madinah, Saudi Arabia.

Al-Sabihi, O. (2009). E -learning of the Quran in the Assembly: Preserving the Holy Quran $\quad . . \quad$ Experience and prospects. Symposium on the Holy Quran and Contemporary Technologies (Information Technology). King Fahd Complex for Printing the Holy Quran, Medina. Kingdom of Saudi Arabia.

Al-Zoubi, A. (2013). Use of Information Technology in the Teaching of Quran Recitation (Qira'at) - Electronic Miqrah as a Model, Paper presented in Taibah University International Conference on
Advances in Information Technology for the Holy Quran and Its Sciences 22-25 Dec. 2013, Madinah, KSA. 10.1109/NOORIC.2013.99.

Hidayat, N. (2017). E-Learning Implementation in Islamic Education Innovation. Hunafa: Jurnal Studia Islamika, 14(1), 17-36. http://dx.doi.org/10.24239/jsi.v14i1.460. $17-36$

Itmazi, J. (2011). E-learning Tools and Technologies at Holy Quran Services between Theory and Practice, Communications of the Arab Computer Society, 4(2), 1-20.

Madani, M. (2010). Using the education technology in Quranic education and its effects on target groups learning, University of Damascus Journal, 26(3), 317-365.

Mohamed, S.A.E., et al. (2014). Virtual Learning System (Miqra’ah) for Quran Recitations for Sighted and Blind Students. Journal of Software Engineering and Applications, 7, 195-205. http://dx.doi.org/10.4236/jsea.2014.7402 1.

Mssraty, T. and Faryad, Q. (2015). Multimedia Instructional Learning System to Aid in Teaching Quran Recitation with Effective Tajweed in Primary Education of Malaysia, International Journal on Islamic Applications in Computer Science And Technology, 3(2), 19-28.

Rajab, A. (2009). The use of e-learning methods adapted to the quality of teaching and learning the Holy Quran. Symposium on the Holy Quran and Contemporary Technologies (Information Technology), King Fahad Complex for Printing the Holy Quran, Madinah, Saudi Arabia. 
Shamsuddin, S., Abu bakar, N., Makhtar, M. Isa, W., Rozaimee, A., Yusof, N. (2016). A Framework For Designing Mobile Quranic Memorization Tool Using Multimedia Interactive Learning Method For Children, Journal of Theoretical and Applied Information Technology, 92(1), 20-27.

Suleiman, H. (2012). The impact of modern technology in preserving the book of Allah: Analytical reading, Paper presented at Annual International Quranic Conference (Muqqadas 2) 22-23/2/2012, The Quran Research Center, Universiti Malaya: Malaysia.
The Ministry of Awqaf and Religious Affairs (n.d.). Teacher's Guide to Using the Quran Distance Learning Program (Handbook), The Ministry of Awqaf and Religious Affairs, Sultanate of Oman. 